\title{
STABILOMETRIC CHANGES DUE TO EXPOSURE TO FIREARM NOISE IN THE BRAZILIAN ARMY
}

\author{
ALTERAÇÕES ESTABILOMÉTRICAS PRODUZIDAS NA EXPOSIÇÃO AO RUÍDO \\ DE ARMA DE FOGO EM MILITARES DO EXÉRCITO BRASILEIRO
}

\section{Luciana Dias BERNARDO'; Eduardo Mendonça SCHEEREN²; Runer Augusto MARSON ${ }^{3}$; Eduardo Borba NEVES ${ }^{4}$.}

1. Mestre em Saúde Coletiva - Universidade Federal do Rio de Janeiro - UFRJ - Instituto de Estudos em Saúde Coletiva - IESC, Rio de Janeiro, RJ, Brasil. ludiasb@gmail.com; 2. Doutor em Engenharia Elétrica e Informática Industrial, Professor, Pontífica Universidade Católica do Paraná, Curitiba, PR, Brasil; 3. Pós Doutor em Engenharia Biomédica, Pesquisador do Instituto de Pesquisa e Capacitação Física do Exército, Rio de Janeiro, RJ, Brasil; 4. Pós Doutor em Engenharia Biomédica, Coronel do Exército Brasileiro, Instituto de Pesquisa e Capacitação Física do Exército, Rio de Janeiro, RJ, Brasil.

\begin{abstract}
Success in precision activities such as shooting depends on the subtle control of body motion. This study aimed to evaluate the influence on stabilometric signal responses for the motor task of aiming a pistol with different cognitive demands and levels of exposure to high sound pressure in Brazilian Army personnel. This cross-sectional analytical study used stabilometry to quantify the behavior of the body during motor, cognitive, and auditory tasks. Twenty-five volunteers recruited to participate in the study completed a questionnaire, underwent anthropometric evaluation and cinemetry, and scored the perceived difficulty during exposure to a sound pressure of $132 \mathrm{~dB}$ while using protective equipment. A significant increase in the displacement $(\mathrm{p}=0,02)$, anteroposterior amplitude $(\mathrm{p}=0,01)$, anteroposterior velocity $(\mathrm{p}=0,01)$, and the perceived difficulty scale $(\mathrm{p}=0,03)$ between Situation 1 (aiming without other cognitive action or environmental noise) and Situation 3 (shooting noise and progressive counting) was confirmed. number of shots heard). Correlation between the perceived difficulty scale and the variables of displacement $(\mathrm{p}=0,01)$, anteroposterior amplitude $(\mathrm{p}=0,01)$, area $(\mathrm{p}=0,006)$ and anteroposterior mean frequency $(\mathrm{p}=0,01)$ were observed. The accuracy of aiming events correlated with the median lateral median frequency $(\mathrm{p}=0,02)$. Stabilometric signals demonstrated increased total displacement, anteroposterior amplitude, and anteroposterior velocity in the presence of high sound pressure levels. These results indicate the need for future studies to investigate the underlying mechanisms of possible vestibular damage induced by noise.
\end{abstract}

KEYWORDS: Posture. Military. Vestibule, Labyrinth. Noise. Occupational Health. Hearing.

\section{INTRODUCTION}

Established relationships between workers' health and work activities are essential determinants in the individual and collective health (BUSS; PELLEGRINI FILHO, 2007). Occupational hazards are often studied in Brazil and worldwide, serving as evidence for improvement in working conditions.

Certain activities in the civilian environment may be similar to those the military but differ in relation to occupational health services. Military personnel are governed by internal orders and regulations that lag behind the civilian environment in terms of occupational safety (NEVES; MELLO., 2007). Routine military service may include exposure to risks and vulnerabilities inherent to the profession (NEVES, 2007).

Among these are the requirements for high levels of physical and mental health; high levels of alertness in the event of possible conflict; the risk of serious injury during combat or training; exposure to harmful agents; and their routine administrative activities (NEVES; MELLO, 2009; ALAMGIR et al. 2016).

A common activity in the Armed Forces and Public Security is shooting practice, which is considered essential and intrinsic (BAPTISTA, 2012; MOREIRA, 2009). The use of weapons in the workplace requires consistency and precision since these determine the physical safety of military and other personnel (LAKIE, 2010; TAVERNIERS; DE BOECK, 2014; NASCIMENTO NETO et al., 2017). Thus, exposure to noise during these activities may occur daily; however, the precise quantification of this noxious exposure in the military is challenging (DAVIS et al., 2018).

Therefore, the type of noise (continuous, intermittent, or impact), exposure time, noise intensity, and susceptibility can result in health problems with a range of severity (BRASIL MINISTÉRIO DA SAÚDE, 2006). 
Stabilometric changes due...

The use of firearms exposes the subject to impact noise (NR-15, 1978). Exposure levels above $130 \mathrm{~dB}(\mathrm{C})$, measured using the Fast Response Circuit (FAST), has been shown to present a serious and imminent auditory risk if users are not adequately protected (NR-15, 1978).

Exposure to impact noise can result in changes in auditory sensitivity and difficulties in auditory discrimination, a limited ability to recognize sounds, a sense of auditory discomfort, tinnitus, and difficulty in understanding speech (PIMENTEL et al., 2016). In addition to psychophysiological damage related to stress, nervousness, irritability, headache, insomnia, postural instabilities, circulatory alterations, altered vision, and gastrointestinal disorders have also been reported (BRASIL MINISTÉRIO DA SAÚDE, 2006; LE et al., 2017).

A sniper's best performance is directly related to postural stability. These vital components provide control and safety of the firing position; any involuntary movement will compromise a sniper's ability LAKIE, 2010; MEINKE et al., 2014; TALCOTT et al., 2012; GOEDERT, 2015). Reactions against internal forces (anxiety, concentration, muscular contractions, or physiological disturbances such as respiration and heartbeat) and external forces (gravitational, inertial, frictional, and reactional) also influence this stability (DAVIS et al. 2018; MEINKE et al., 2014; TALCOTT et al., 2012; GOEDERT, 2015; LOURENÇO; SILVA, 2013).

Stabilometry is one of the most widely used quantitative research methods to measure postural stability. This method detects neuromechanical responses in multiple directions to maintain balance and is considered the most sensitive method to detect vestibular changes due to noise exposure (FARIAS, 2017). However, its use is still low in promoting worker health.

In shooting practitioners, a small body swing can be the difference between striking or missing a target. Understanding the behavior of balance during this task can provide information to improve these aspects in military training. This training aims to ensure efficient shooting to minimize and combat the risks of friendly fire (fratricide) which can result in unintentional deaths or damage to a companion (PACHECO, 2004).
BERNARDO, L. D. et al.

Any vulnerability that may influence the performance of military activities can mean not only injury to an individual but also to whole groups (NEVES; MELLO, 2009). In this sense, the objective of this study was to evaluate the influence of exposure to the high sound pressure level (SPL) by stabilometry during the motor task of aiming with a pistol along with different cognitive demands among military personnel in the Brazilian Army. The findings of this research may increase the understanding of the reactions to SPL, leading to the development of adaptations of training programs to promote the occupational health of the military.

\section{MATERIAL AND METHODS}

This cross-sectional study was approved by the Ethics and Research Committee (CEP) of Hospital Naval Marcílio Dias on March 20, 2018 (opinion: 2,552,409). The experiment was conducted at the Brazilian Army Research Institute of Physical Fitness in Rio de Janeiro.

\section{Participants}

The sample population comprised 25 male soldiers (age: $18.76 \pm 0.52$ years, weight: $66.65 \pm$ $6.28 \mathrm{~kg}$, and height: $1.75 \pm 0.06 \mathrm{~m}$ ). The body mass index (BMI) $\left(24.23 \pm 3.66 \mathrm{~kg} / \mathrm{m}^{2}\right)$ and shoe size $(41.32 \pm 1.10)$ were used to standardize and characterize volunteers. The volunteers were asked to present themselves for signing the informed consent term.

\section{Procedures}

The instruments used for data collection were portable acoustic system LRAD100X; a questionnaire; anthropometric assessment; stabilometric evaluation; cinemetry; perceived difficulty scale; and data analysis on IBM SPSS Statistics 2.1 software, described in the following sections.

The experimental design was composed of three different shooting situations: Situation 1, aiming with no other cognitive action or environmental noise; Situation 2, aiming with regressive mental count and without environmental noise; and Situation 3, aiming with shooting noise and progressive count of the number of shots heard. The research phases are shown in Figure 1. 


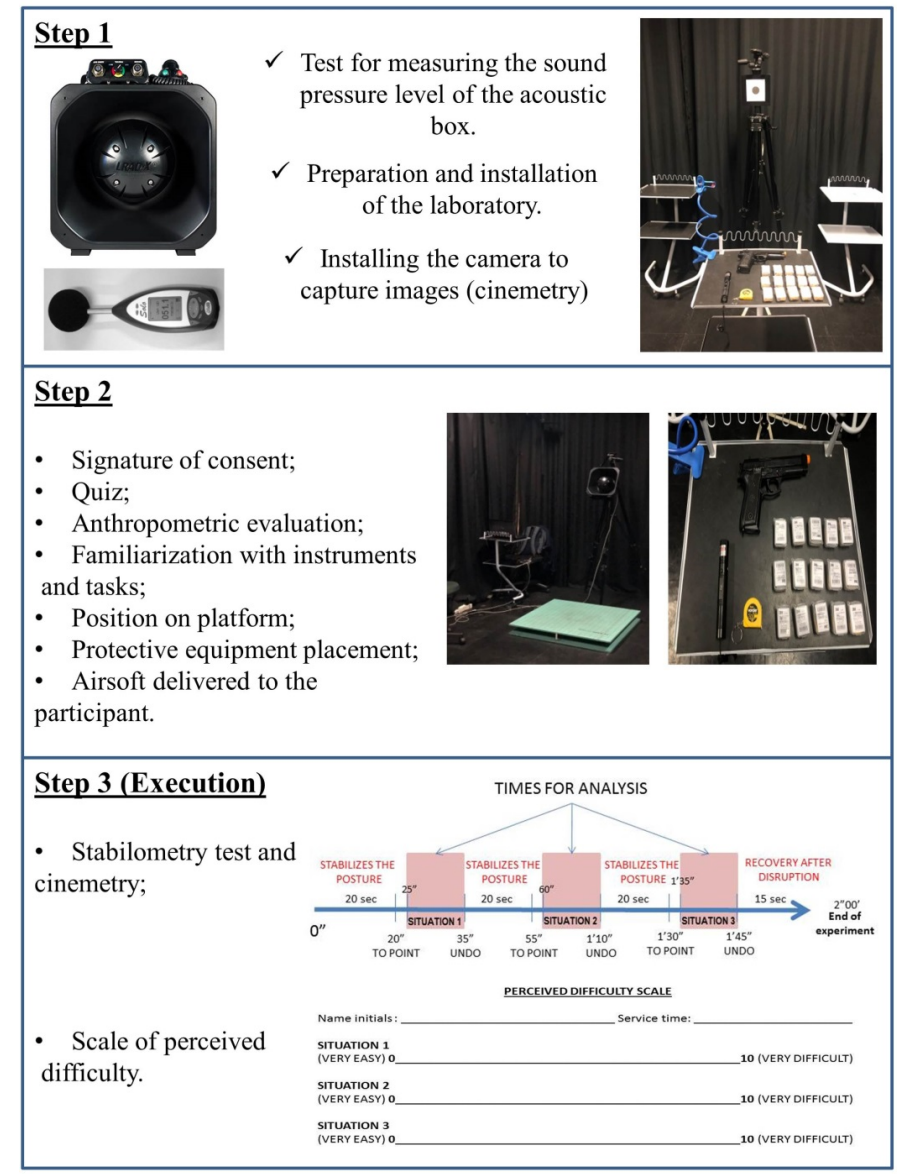

Figure 1. Diagram of the study process

\section{Anthropometric evaluation}

Measurements of height, body mass, BMI, and shoe size were obtained. Measurements were performed using a Personal Stadiometer Caprice Sanny and a Balmak advanced scale, class III. BMI was calculated using the following formula: $\mathrm{BMI}=$ weight $(\mathrm{kg}) /$ height $^{2}\left(\mathrm{~m}^{2}\right)$. Footwear size was selfreported by the participants.

\section{Stabilometry}

A 16-bit resolution platform, calibrated at a 1,000-fold gain, with a low-pass filter of $23 \mathrm{~Hz}$ and a sampling frequency of $500 \mathrm{~Hz}$, was used for a force platform (EMG System do Brasil Ltda., model Biomec 400, year 2011), with a gain of 600 and a common rejection module $>90 \mathrm{~dB}$ connected to a microcomputer with EMGLAB (EMG System do Brasil Ltda.) analysis software. This platform measures $1,000 \times 1,000 \mathrm{~mm}$ with four load cells and an internal circuit that changes the electrical resistance by applying a force with an accuracy of $0.5 \%$.

During the test, the displacements of the center of pressure $(\mathrm{CP})$ in the mediolateral (ML, X) and anteroposterior (AP, Y) directions and the ability to return to the baseline state after a temporary disturbance (sound stimulus) were evaluated.

The volunteers remained with their arms along the body, with the base of their feet free (similar to the preparation in the training of shooting), and without inclination or lateralization of position. They were asked to fix their eyes on a target positioned $2 \mathrm{~m}$ away and at a height adjusted with respect to the height of the volunteer (approximately $1.70 \mathrm{~m}$ ). The target measured $14 \times$ $14 \mathrm{~cm}$ and consisted of 10 concentric circles.

The participants held an Airsoft Taurus PT92 pistol weighing $230 \mathrm{~g}$. The replica was fitted with a green laser pointer pen so that the participants could visualize and focus their aim on the target. During the experiment, the participants used an auditory protection equipment (3M ${ }^{\mathrm{TM}} 1291$ earplugs with a noise reduction rating-subject fit [NRRsf] of $16 \mathrm{~dB}$ ) similar to that employed in shooting training.

The duration of the test was 120 seconds to prevent fatigue from maintaining the same posture, which could affect the results (ALONSO, 2012; DUARTE; FREITAS, 2010).

Each analyzed motor task lasted 10 seconds, with the following variations: Situation 1 (S1), 
aiming; S2, aiming with a cognitive task (silent countdown); and S3, aiming with a cognitive task (counting of shots) and auditory stimulus (disturbance that simulated a sequence of shots by firearm).

\section{Sound stimulation}

Sound stimulation was generated by a Long Range Acoustic Device (LRAD) 100X portable system. For the system to reproduce the characteristic sound of firearm shots with the same intensity as a real weapon, a test was performed using a sound pressure level meter (brand $01 \mathrm{~dB}$ Metravib, Solo model, serial number: 341) to measure the intensity of the shots in $\mathrm{dB}(\mathrm{C})$. Three measurements were collected, with a 45 -second interval between each measurement and with levels ranging from 131.7 to $132.3 \mathrm{~dB}(\mathrm{C})$, with an average of $132 \mathrm{~dB}(\mathrm{C})$.

The amplifier was positioned behind the participant and centered at a 30 -degree angle to the center of the box, $1 \mathrm{~m}$ away, and $1.70 \mathrm{~m}$ from the ground.

MP4 audio was saved in the speaker memory to control the evaluated motor tasks together with the presentation of firearm shots (sound disturbance) occurring together with the 120 seconds of the examination.

The participants were informed individually about what they would hear in the audio and what tasks should be performed for each command: "aim," to aim at the installed target, or "Ok," to lower the replica firearm and return the arms to a position parallel to the body. The sound disturbance occurred between 1'35 "and 1'45".

$$
\begin{aligned}
& \text { Audio playback: } \\
& \text { At 20": "aim" (Situation 1) } \\
& \text { At 35": "ok" } \\
& \text { At 50": "countdown" } \\
& \text { At 55": "aim" (Situation 2) } \\
& \text { At 1'10": "ok" } \\
& \text { At 1'25": "shot count" } \\
& \text { At 1'30": "aim" (Situation 3) } \\
& \text { At 1'45": "ok" }
\end{aligned}
$$

\section{Cinemetry}

To monitor the displacement of the shooting aim, the cinemetry relied on recorded images of the target and shooting aim via a laser pointer, which was used during the experiment.

A smartphone camera (Apple, iPhone 8S) was used to record the displacement of the image of the laser pointer that indicated the target aim. The equipment was attached to a tripod below the target, and the images were captured in slow motion; recorded at 240 frames per second in high definition; and then transferred to a computer for observation and analysis. The pointer shifts were extracted from three visual references based on the aim arising out of the $7,8,9$, and 10 rays (central target) during the three test protocols.

The videos were transferred to a computer and analyzed by the researcher using the observation method for the number of displacements viewed through the laser sight that were outside the central layers.

\section{Scale of perceived difficulty}

To measure the perception of difficulty of different motor tasks by individuals, an instrument using a visual analog scale was widely used in different studies (FIGUEIREDO, 2007). The instrument aimed to measure (quantify) a subjective sensation without the intention of confusing the actual values found in postural oscillations.

A $10-\mathrm{cm}$ non-graduated line was used to measure the participants' perceptions. The left side indicated " 0 " (very easy), while the right side indicated "10" (very difficult). Each participant was asked to draw a vertical line at the graduation point where he perceived his difficulty to be in relation to the three tasks requested. The answers were measured using the same scale to standardize the measurements.

\section{Data analysis}

The data obtained by the force platform were partitioned into 10 -second windows for each of the three situations. For each window, the following stabilometric variables were measured: AP and ML mean position, total displacement, AP and ML amplitudes, area, direction of oscillation, $\mathrm{AP}$ and $\mathrm{ML}$ velocities, AP and ML median frequencies, and $\mathrm{AP}$ and ML mean frequencies.

The data were compiled into an Excel spreadsheet and imported for storage and analysis in IBM SPSS Statistics, version 21.0.

The distributions of the variables were tested using Shapiro-Wilk tests. The results were expressed as means \pm standard deviation. For the comparison of the study variables between the three moments of "aim," Tukey post hoc variance analysis was used, with a significance level of 95\% $(\mathrm{P}<0.05)$. A linear association measure (Pearson's correlation coefficient) was used to verify the correlations between the difficulty scale and the non-target aim events with the stabilometric variables. 


\section{RESULTS}

The sample consisted of 41 male military men, with an average age of 18.76 years (ranging from 18 to 19 years). Eleven participants were excluded from the study after a technical failure to receive the signal from the platform; an additional five participants were excluded because they did not meet the inclusion criteria. Four volunteers reported headache and pain in the lumbar spine but were not excluded because these were isolated symptoms. Four participants had visual impairment; however, they used corrective lenses. Thus, 25 entered as valid data in this study.

Table 1 shows the characteristics of the included individuals.

Table 1. Characteristics of the 25 Brazilian Army soldiers included, Rio de Janeiro, Brazil, 2018

\begin{tabular}{llcccl}
\hline Variable & N & Minimum & Maximum & Mean & SD \\
\hline Age (years) & 25 & 18 & 19 & 18.76 & 0.52 \\
Body mass $(\mathrm{kg})$ & 25 & 55,0 & 79.0 & 66.68 & 6.28 \\
Height $(\mathrm{cm})$ & 25 & 1.62 & 1.95 & 1.75 & 0.06 \\
Body Mass Index $\left(\mathrm{kg} / \mathrm{m}^{2}\right)$ & 25 & 18.16 & 25.79 & 24.23 & 3.66 \\
Shoe size & 25 & 39 & 43 & 41.32 & 1.10 \\
\hline
\end{tabular}

Table 2 shows the total averages and standard deviations by variable and situation. Values with "*" have significant differences after performing Tukey post hoc analysis of variance.

The table shows statistical differences in the comparisons between Situations 1 and 3, confirming an increase in oscillations between motor and motor cognitive tasks with the presence of SPL. A significant difference was also observed between the two- and three-point approaches in the AP velocity. Thus, high SPL seemed to be responsible for the increase in postural oscillation observed in displacement, AP amplitude, and AP velocity. Moreover, increased perceptions of difficulty between the same situations were confirmed by the participants themselves.

Table 2. Means and standard deviation of the protocols per variable according to the recorded stabilometric signals

\begin{tabular}{lllll}
\hline Variable & N & Situation 1 & Situation 2 & Situation 3 \\
\hline PosAP $(\mathrm{cm})$ & 25 & $3.305 \pm 0.988$ & $3.338 \pm 1.008$ & $3.268 \pm 0.942$ \\
PosML(cm) & 25 & $0.474 \pm 0.540$ & $0.474 \pm 0.541$ & $0.484 \pm 0.558$ \\
Displac (cm)* & 25 & $2.392 \pm 0.590$ & $2.563 \pm 0.725$ & $3.061 \pm 1.152$ \\
AmplAP (cm)* & 25 & $0.306 \pm 0.103$ & $0.342 \pm 0.126$ & $0.428 \pm 0.196$ \\
AmplML (cm) & 25 & $0.160 \pm 0.053$ & $0.188 \pm 0.083$ & $0.196 \pm 0.081$ \\
${\text { Area }\left(\mathrm{cm}^{2}\right)}_{\text {OscDir (o) }}^{25}$ & $0.035 \pm 0.021$ & $0.040 \pm 0.029$ & $0.054 \pm 0.042$ \\
VelAP (cm/s)** & 25 & $-16.392 \pm 7.656$ & $-17.984 \pm 6.099$ & $-15.048 \pm 6.175$ \\
VelML (cm/s) & 25 & $0.153 \pm 0.042$ & $0.162 \pm 0.053$ & $0.207 \pm 0.087$ \\
FreqMedianAP (Hz) & 25 & $0.154 \pm 0.041$ & $0.167 \pm 0.047$ & $0.186 \pm 0.067$ \\
FreqMedianML (Hz) & 25 & $0.520 \pm 0.163$ & $0.520 \pm 0.163$ & $0.592 \pm 0.196$ \\
FreqMAP (Hz) & 25 & $1.016 \pm 0.336$ & $1.056 \pm 0.262$ & $1.104 \pm 0.265$ \\
FreqMML (Hz) & 25 & $0.518 \pm 0.167$ & $0.532 \pm 0.182$ & $0.574 \pm 0.172$ \\
DIFSCALE (cm)* & 25 & $1.014 \pm 0.267$ & $1.050 \pm 0.196$ & $1.065 \pm 0.216$ \\
\hline
\end{tabular}

$* \mathrm{P}<0.05$ between Situations 1 and $3 ; * * \mathrm{P}<0.05$ between moments 1 and 3 and 2 and 3

Abbreviations: PosAP, anteroposterior mean position; PosML, medio-lateral mean position; Displac, total displacement; AmplAP, anteroposterior amplitude; AmplML, medio-lateral amplitude; OscDir, area, oscillation direction; VelAP, anteroposterior velocity; VelML, medio-lateral velocity; FreqMedianAP, anteroposterior median frequency; Medio-lateral median frequency, FreqMedianML; FreqMAP, anteroposterior mean frequency; FreqMML, medio-lateral mean frequency; DIFSCALE, perceived difficulty scale

Table 3 shows the number of observations of aims outside the center of the target. While the differences were not significant, there was a tendency toward an increased number of events from Situation 1 to Situation 3. 
Table 3. Total means of aims outside the target during the experiment

\begin{tabular}{llcccl}
\hline Target events outside the target center & N & Minimum & Maximum & Mean & SD \\
\hline S1 & 25 & 0 & 9 & 2.55 & 2.46 \\
S2 & 25 & 0 & 12 & 2.91 & 2.60 \\
S3 & 25 & 0 & 11 & 3.29 & 2.93 \\
\hline
\end{tabular}

Label: S1 (Situation 1: motor task), S2 (Situation 2: motor-cognitive task), S3 (Situation 3: motor-cognitive-auditory task)

Table 4 shows the Pearson's correlation coefficients between the mean values of the three pointers of each stabilometric variable with the means of the results of the perceived difficulty scale and pointer displacement from the target. A strong correlation was observed between the difficulty scale and displacement, AP amplitude, area, and AP mean frequency, whereas the accuracy of the aim events was correlated with the median ML frequency.

Table 4. Pearson's correlation coefficient between the mean values of the stabilometric variables, the perceived difficulty scale, and the accuracy of the aim (non-target marks)

\begin{tabular}{lccl|ccc}
\hline & \multicolumn{3}{c|}{ DIF scale (cm) } & \multicolumn{3}{c}{ Target events outside the target center } \\
\cline { 2 - 7 } & $\begin{array}{c}\text { Pearson's } \\
\text { correlation }\end{array}$ & CI & P value & $\begin{array}{c}\text { Pearson's } \\
\text { correlation }\end{array}$ & CI & P value \\
\hline PosAP (cm) & -0.727 & $-9,456-8,003$ & 0.482 & -0.541 & $-11,224-10,141$ & 0.636 \\
PosML (cm) & 0.965 & $-2,385-4,314$ & 0.17 & 0.874 & $-5,307-7,054$ & 0.323 \\
Displac (cm) & $\mathbf{1 . 0 0 0}^{*}$ & $\mathbf{0 , 7 6 9 - 1 , 2 3 1}$ & $\mathbf{0 . 0 1 2}$ & 0.967 & $-2,293-4,226$ & 0.165 \\
AmplAP (cm) & $\mathbf{1 . 0 0 0}^{*}$ & $\mathbf{0 , 6 8 8 - 1 , 3 1 1}$ & $\mathbf{0 . 0 1 6}$ & 0.977 & $-1,756-3,709$ & 0.138 \\
AmplML (cm) & 0.843 & $-5,984-7,670$ & 0.361 & 0.947 & $-3,122-5,016$ & 0.208 \\
Área (cm $\left.\mathbf{c m}^{2}\right)$ & $\mathbf{1 . 0 0 0}$ & $\mathbf{0 , 8 7 2 - 1 , 1 2 8}$ & $\mathbf{0 . 0 0 6}$ & 0.969 & $-2,192-4,129$ & 0.16 \\
OscDir (o) & 0.668 & $-8,786-10,122$ & 0.534 & 0.471 & $-10,737-11,679$ & 0.688 \\
VelAP (cm/s) & 0.994 & $-0,408-2,396$ & 0.07 & 0.939 & $-3,440-5,317$ & 0.224 \\
VelML (cm/s) & 0.989 & $-0,898-2,875$ & 0.095 & 0.996 & $-0,174-2,166$ & 0.059 \\
FreqMedian AP (Hz) & 0.965 & $-2,385-4,314$ & 0.17 & 0.874 & $-5,307-7,054$ & 0.323 \\
FreqMedian ML (Hz) & 0.979 & $-1,600-3,558$ & 0.13 & $\mathbf{0 . 9 9 9}$ & $\mathbf{0 , 5 3 1 - 1 , 4 6 7}$ & $\mathbf{0 . 0 2 3}$ \\
FreqMAP (Hz) & $\mathbf{1 . 0 0 0}$ & $\mathbf{0 , 6 9 3 - 1 , 3 0 7}$ & $\mathbf{0 . 0 1 5}$ & 0.965 & $-2,368-4,298$ & 0.169 \\
FreqMML (Hz) & 0.882 & $-5,101-6,865$ & 0.312 & 0.969 & $-2,162-4,100$ & 0.159 \\
\hline
\end{tabular}

*The correlation is significant at the 0.05 level ( 2 standard deviations); **The correlation is significant at the 0.01 level (2 standard deviations).

\section{DISCUSSION}

With the aim to determine the influence of high SPL and the demand for cognitive tasks in maintaining balance in military personnel exposed to shooting activities, the results of this study revealed an increased postural oscillation before an activity with a disturbing auditory factor.

Significant differences were found in the total displacement variables (between S1 and S3), AP amplitude (between S1 and S3), and AP velocity (between S1 - S3 and S2 - S3), showing increased values for the task in which SPL was presented. In the subjective perception scale of the difficulty, there was also a significant difference between S1 and S3. The results indicate that the SPL can increase the postural oscillation in shooting tasks that require controlled and precise postures.

The increased postural oscillations observed in the present study corroborate with those by Park et al. (2011), who reported increased oscillations as
SPL intensity increased, although without statistical significance. Park used three levels of intensity (45, 90 , and $120 \mathrm{~dB}$ ) and frequencies $(1,2,3$, and $4 \mathrm{kHz})$ to analyze the effects the combined sounds on the participants' quiet posture. The authors used variables such as position variability of $\mathrm{CP}$ and the length of the postural oscillation pathway in the AP and ML directions, which were significantly longer in the $3-\mathrm{kHz}$ and $4-\mathrm{kHz}$ frequencies. No interaction with ML oscillation nor association with SPL were observed (PARK et al., 2011).

Azevedo et al. (2016) evaluated the participants exposed to noise intensities of 95-100 $\mathrm{dB}$ at frequencies of $400,2,000,4,000$, and 8,000 $\mathrm{Hz}$, with and without hearing protectors. Of the analyzed variables ( $\mathrm{CP}$ area and $\mathrm{ML}$ and $\mathrm{AP}$ displacements in oscillation) did differ significantly between the test conditions (AZEVEDO et al., 2016).

$\mathrm{Xu}$ et al. (2018) reported a sound stimulus below $85 \mathrm{~dB}(\geq 46.6 \mathrm{~dB})$ bilaterally through portable 
listening devices, which indicates an association between low-frequency sound $(100 \mathrm{~Hz})$ and lower oscillations in the displacement data and posturography. At frequencies of 1,000 and 4,000 $\mathrm{Hz}$, we did not find any correlation between examination scores.

Mainenti et al. (2007) tested the stabilometric variables with and without a stimulus of $70 \mathrm{~dB}$ above the auditory threshold and with eyes open or closed. No statistical differences were observed in oscillation area, mean position (AP and $\mathrm{ML}$ ), or mean frequency (AP and ML) in relation to postural changes during sound stimulation with pure tones (continuous tones used in audiometric tests). The mean velocities (AP and ML) and displacement showed statistically significant differences either with the withdrawal or absence of withdrawal of the visual cues but not sound. The acoustic stimuli used in that study were at safe intensities for hearing health, unlike those in the present study.

In Alessandrini et al.'s study (2006), the healthy participants, with a mean age of 29.3 years, were asked to listen to sounds ranging from $500 \mathrm{~Hz}$ to $130 \mathrm{~dB}$ in the right ear only, and no significant differences were observed in the mean frequency ML, oscillation area, and mean velocity; however, the mean velocity standard deviation showed a statistically significant increase in oscillations in the presence and absence of sound with open eyes. The sound stimulus induced a vestibular activation expressed through the contraction of the lower limbs (reflex postural vestibule) since there was a decrease in the dispersion of the standard deviation marked by the greater standardization of reflex responses induced by the vestibular system.

Similar to the methodology used in the previous study, Majewska et al. (2017) examined the normal-hearing participants, performing the experiment with stimulations ranging from $4 \mathrm{kHz}$ to $65 \mathrm{~dB}$ and observed improved stability in the mean velocity of the $\mathrm{CP}$ in the absence and presence of sound. SPL below $85 \mathrm{~dB}$ does not pose a danger to hearing health. Therefore, safe intensities or sound cues present at conversational levels can help increase concentration and improve the effective use of proprioceptors (NR-15, 1978; MAJEWSKA et al, 2017).

To elucidate how the human ear reacts to each sound frequency, Siedlecka et al. (2015) used different frequencies at $80 \mathrm{~dB}$ and reported an improvement in oscillation areas at a $4-\mathrm{kHz}$ stimulus. Low frequencies did not register any oscillation in the presence or absence of sound. The amplitudes and mean velocities in the AP and ML directions did not change. These results indicate that postural oscillation depends on the frequency of sound.

The results of previous studies do not necessarily contradict the findings of the present study because none of them used bilateral exposure to impact noise along with shooting position; however, all of these studies analyzed the effects of acute exposure. The literature data on the immediate impact of shooting noise on the postural balance of participants are limited, making it difficult to compare findings. However, the effects of chronic exposure to noise on the functioning of the vestibular system are well explored (LE et al., 2017; STEWART et al., 2016). Continuous exposure to noise is widely studied in occupational health because it is a more common agent in daily work function.

Situation 2 simulated a situation requiring cognitive attention, in which the military personnel must be alert to count shots fired for re-loading their weapons in a real combat situation. We observed no statistically significant differences between Situation 1 and Situation 2, suggesting that dual tasks (motor and cognitive) did not influence the postural oscillations and, consequently, did not interfere during shooting.

Dual tasks are reportedly beneficial for participants with poor postural balance, improving the processing of multiple information and reducing postural oscillations. A meta-analysis study observed inverse correlations and revealed that complexity factors within a dual task play a role in improving stability by reducing AP oscillation (GHAI; GHAI; EFFENBERG, 2017), which corroborates the results of a previous cohort study in which the dual task consisting of a countdown was associated with a reduced AP oscillation (KANG; LIPSITZ, 2010).

However, the same cohort study reported significantly increased ML oscillation when double tasks were performed (KANG; LIPSITZ, 2010), and the harmful effects of double tasks on the postural stability were reported in population groups vulnerable to falls, those with neurological disorders, and healthy young people, suggesting that attention shifts or increased multisensory demand may increase stress, reflect the level of arousal, and disrupt conscious control, thereby reducing stability (STEWART et al., 2016; KANG et al., 2009).

The stabilometric variables of displacement, AP amplitude, area, and AP mean frequency showed a positive linear correlation with the subjective classifications of the perceived difficulty, demonstrating that as the oscillations between aims 1,2 , and 3 increased so did the perceived difficulty. 
This increased difficulty was also observed in the cinemetry analysis, in which increased oscillation in the aim was observed when the cognitive demand changes, mainly when the sound stimulus was added, which was attributed to an increased demand for attention from the participant (KANG et al., 2009). Among the activities associated with aiming, a significant positive linear correlation was observed for the median ML frequency.

In the present study, participants were able to perform the experiment with their eyes open, and this sensory input (vision) was responsible for superior results in the equalization of postural oscillation, alleviating the effects of vestibular inputs on balance control (PARK et al., 2011; YOON et al., 2012; AZEVEDO et al., 2016).

The individuals maintained a mean BMI for healthy individuals $\left(24.23 \pm 3.66 \mathrm{~kg} / \mathrm{m}^{2}\right)$, excluding a possible bias in the analyses by anthropometric indices. Some studies have indicated that individuals with BMI within normal or overweight ranges do not have a disturbance in balance (ALONSO, 2012); however, others did not observe a correlation between the parameters of postural stability and BMI (MAJEWSKA et al. 2017; XU et al., 2018).

The age range in this study is consistent with those in the studies by Mainenti et al. (2007) and Park et al. (2011) and has also been associated with changes in postural oscillation. Oscillation reportedly increases with age, especially in the ML and AP directions (YOON et al., 2012; DORNELES; SILVA; MOTA, 2015). Patti et al. (2018) reported that mean AP oscillations are better for youngsters, although their balance worsens slightly to the right in the ML position compared to those in the elderly individuals. The above results are relevant when we observe that the increased variables of the present study were in the direction where in the literature, one expects more stability for the presented age.

To ensure the validity of the support base in stabilometry measurements, the same foot spacing and rotation performed in military activities were used as the standard. A survey of factors that could affect balance in posturography measured three different positions of the feet and found increased oscillations in CP displacement and ML velocities at the narrowest base. However, there was no difference in the AP direction (YOON et al, 2012). Reduced posture oscillations are observed with an increasing base of support, with better results observed with the feet apart for all stabilometric variables in postural firing tests (ALONSO, 2012; PINHO, 2011).
Research shows that gunshot positioning registers increased oscillations in both the ML and AP velocities, especially the ML (LOURENÇO; SILVA, 2013). Reduced oscillation in the AP direction is the largest predictor of efficient shots and can occur significantly more often than that in ML direction for this activity, as revealed in our study (AZEVEDO et al., 2016).

This study had some limitations, including the lack of information on the range of sound frequencies to which the individuals were exposed, which could warrant additional studies using frequency variations; a lack of randomization of the experimental situations due to logistic limitations; the risk of the results being influenced by learning factors; the restricted age range; the lack of generalization of the results to other age groups; the use of hearing protection equipment in cases of harmful exposure, which may attenuate up to $16 \mathrm{~dB}$ of the acoustic stimulus; the differences between the weight of a real and a replica weapon; the use of iPhone for cinemetry evaluation without utilizing a valid measurement program; and the lack of research that can evaluate both the balance of impulse noise and studies that recorded all variables provided in the stabilometric test for a complete discussion of the results.

Unhealthy exposure to impact noise is a particularly important problem in the Armed Forces; however, wearing a hearing protector during missions can compromise the safety of military personnel. Faced with this, unhealthy exposure is inevitable.

Stabilometric signals revealed increased total displacement, AP amplitude, and AP velocity before high SPL while aiming a pistol, corroborating the participants' perceived scale of difficulty. We also observed an increase in the number of inaccurate targets, with increasing cognitive demand and high SPL.

The present study filled the gap in the literature regarding the influence of impact noise on the vestibular system while firing, performing activities related to figure a gun. The results provide a basis for future studies to investigate the underlying mechanisms of vestibular damage from high SPL and to advance the development of health actions in exposed subpopulations.

Based on the results, it is possible to advance the development of actions in military training to prevent noise-induced vestibular deficits and assess possible adjustments in the subject's positioning during fire practice.

While studies of the consequences of impact noise on the auditory system are well documented, 
especially in workers' health, little is known about its effect on balance. Due to the anatomical proximity of both organs, it is necessary to evaluate populations regularly exposed to these harmful agents.

RESUMO: O sucesso em atividades de precisão, como o tiro, depende do sutil controle das oscilações corporais. Analisar a influência nas respostas do sinal estabilométrico para a tarefa motora de pontaria com pistola, acrescidas de diferentes demandas cognitivas e exposição ao nível de pressão sonora elevado, em militares do Exército Brasileiro. Estudo de caráter transversal analítico utilizou a estabilometria para quantificar o comportamento do corpo durante três situações de pontaria distintas (variando tarefas motoras, cognitivas e auditivas). Vinte e cinco voluntários foram submetidos à pesquisa e utilizou-se: questionário, avaliação antropométrica, cinemetria, escala de dificuldade percebida e exposição ao nível de pressão sonora de $132 \mathrm{~dB}$, com uso do equipamento de proteção individual. Confirmou-se um aumento significativo nas variáveis de deslocamento $(p=0,02)$, amplitude anteroposterior $(p=0,01)$, velocidade anteroposterior $(p=0,01)$ e a escala de dificuldade percebida $(\mathrm{p}=0,03)$ entre a Situação 1 (pontaria sem outra ação cognitiva ou ruído ambiental) e a Situação 3 (pontaria com ruído de tiros e contagem progressiva do número de disparos ouvidos). Observou-se correlação entre escala de dificuldade percebida e as variáveis deslocamento $(p=0,01)$, amplitude anteroposterior $(\mathrm{p}=0,01)$, área $(\mathrm{p}=0,006)$ e frequência média anteroposterior $(\mathrm{p}=0,01)$. A precisão dos eventos de pontaria se correlacionou com a frequência mediana médio lateral $(p=0,02)$. Os sinais estabilométricos demonstraram um aumento nas oscilações do deslocamento total, amplitude ântero-posterior e a velocidade ântero-posterior, na presença de um nível de pressão sonora elevado. O resultado motiva a expansão de estudos futuros, visando averiguar os mecanismos subjacentes dos possíveis danos vestibulares induzidos por ruído.

PALAVRAS-CHAVE: Postura. Militares. Sistema Vestibular. Ruído. Saúde do Trabalhador. Audição.

\section{REFERENCES}

ALAMGIR, H.; TURNER, C. A.; WONG, N. J.; COOPER, S. P.; BETANCOURT, J. A.; HENRY, J., et al. The impact of hearing impairment and noise-induced hearing injury on quality of life in the active-duty military population: challenges to the study of this issue. Mil. Med. Res., v. 3, n. 11, p. 1-8. 2016.

https://doi.org/10.1186/s40779-016-0082-5

ALESSANDRINI, M.; LANCIANI, R.; BRUNO, E.; NAPOLITANO, B.; DI GIROLAMO, S. Posturography frequency analysis of sound-evoked body sway in normal subjects. Eur. Arch. Otorhinolaryngol. v. 263, n. 3, p. 248-252. 2006. https://doi.org/10.1007/s00405-005-0965-7

ALONSO, A. C. A influência dos fatores antropométricos no equilíbrio postural: a relação entre a composição corporal e medidas posturográficas em adultos jovens. [tese]. São Paulo: Universidade de São Paulo; 2012. Disponível em: < http://www.teses.usp.br/teses/disponiveis/5/5160/tde-09082012-140737/pt-br.php>.

AZEVEDO, R.; TEIXEIRA, N.; ABADE, E.; CARVALHO, A. Effects of noise on postural stability when in the standing position. Work., v. 54, n. 1, p. 87-91. 2016. https://doi.org/10.3233/WOR-162280

BAPTISTA, M. T. Análise espectral da flutuação de pontaria e influência da oscilação postural no desempenho de atiradores. [dissertação]. Rio de Janeiro: Universidade Federal do Rio de Janeiro; 2012. Disponível em: $<$ http://www.peb.ufrj.br/teses/Tese0175_2012_12_11.pdf>

BRASIL. MINISTÉRIO DA SAÚDE. Secretaria de Atenção à Saúde. Departamento de Ações Programáticas Estratégicas. Perda auditiva induzida por ruído (PAIR). Brasília: Editora do Ministério da Saúde; 2006.

BUSS, P. M.; PELlEGRINI FILHO, A. A saúde e seus determinantes sociais. Physis (Rio J.), v. 17, n. 1, p. 77-93. 2007. https://doi.org/10.1590/S0103-73312007000100006 
DAVIS, S. K.; CALAMIA, P. T.; MURPHY, W. J.; SMALT, C. J. In-ear and on-body measurements of impulse-noise exposure. Int. J. Audiol. v. 58, n. Sup1, p S49-S57. 2018.

https://doi.org/10.1080/14992027.2018.1534012

DORNELES, P. P.; SILVA, F. S.; MOTA, C. B. Comparação do equilíbrio postural entre grupos de mulheres com diferentes faixas etárias. Fisioter. Pesqui. v. 22, n. 4, p. 392-397. 2015

DUARTE, M.; FREITAS, S. M. S. F. Revisão sobre posturografia baseada em plataforma de força para avaliação do equilíbrio. Rev. Bras. Fisioter. v. 14, n. 3, p. 183-192. 2010. https://doi.org/10.1590/S141335552010000300003

FARIAS, R. V. Avaliação do equilíbrio estático após a indução de fadiga muscular em membros inferiores. [dissertação]. Teresina: Universidade Federal do Piauí; 2017. Disponível em: $<$ http://repositorio.ufpi.br/xmlui/handle/123456789/1047>.

FIGUEIREDO, Rodrigues. Análise crítica dos métodos de mensuração do zumbido. Rev. Bras. Otorrinolaringol., v. 73, n. 3, p. 418-23, 2007. https://doi.org/10.1590/S0034-72992007000300019

GHAI, S.; GHAI, I.; EFFENBERG, A. O. Effects of dual tasks and dual-task training on postural stability: a systematic review and meta-analysis. Clin. Interv. Aging., v. 12, n. 1, p. 557-577. 2017. https://doi.org/10.2147/CIA.S125201

GOEDERT, A. Efeito da prática de pilates sobre o equilíbrio de atiradores. [dissertação]. Curitiba: Universidade Federal do Paraná; 2015. Disponível em: $<$ https://acervodigital.ufpr.br/bitstream/handle/1884/37887/R\%20-\%20D\%20$\% 20$ ARACELI\%20GOEDERT.pdf? sequence=1\&isAllowed=y $>$.

KANG, H. G.; COSTA, M. D.; PRIPLATA, A. A.; STAROBINETS, O. V.; GOLDBERGER, A. L.; PENG, C. K. et al. Frailty and the degradation of complex balance dynamics during a dual-task protocol. J. Gerontol. A. Biol. Sci. Med.Sci., v. 63, n. 12, p. 1304-1311, 2009. https://doi.org/10.1093/gerona/glp113

KANG, H. G.; LIPSITZ, L. A. Stiffness control of balance during quiet standing and dual task in older adults: the MOBILIZE Boston Study. J. Neurophysiol., v. 104, n. 6, p. 3510-3517. 2010.

https://doi.org/10.1152/jn.00820.2009

LAKIE, M. The influence of muscle tremor on shooting performance. Exp. Physiol. v. 95, n. 3, p. 441-450. 2010. https://doi.org/10.1113/expphysiol.2009.047555

LE, T. N.; STRAATMAN, L. V.; LEA, J.; WESTERBERG, B. Current insights in noise-induced hearing loss: a literature review of the underlying mechanism, pathophysiology, asymmetry, and management options. J. Otolaryngol. Head and Neck. Surg.v. 46, p. 41. 2017. https://doi.org/10.1186/s40463-017-0219-x

LOURENÇO, C. P.; SILVA, A. L. S. Controle postural e sistema vestíbulo-oculomotor em atletas de tiro esportivo da modalidade pistola. Rev. Bras. Med. Esporte.v. 19, n. 5, p. 313-316. 2013.

https://doi.org/10.1186/s40463-017-0219-x

MAINENTI, M. R.; DE OLIVEIRA, L. F.; DE MELO TAVARES DE LIMA, M. A.; NADAL, J.

Stabilometric signal analysis in tests with sound stimuli. Exp. Brain Res. v. 181, n 2, p. 229-236. 2007. https://doi.org/10.1007/s00221-007-0921-4

MAJEWSKA, A.; KAWAŁKIEWICZ, W.; HOJAN-JEZIERSKA, D.; JEZIERSKA, A.; KUBISZ, L. The influence of the acoustic stimulus on postural stability. Actabioeng. Biomech.v. 19, n. 2, p. 113-119. 2017. 
MEINKE, D. K.; MURPHY, W. J.; FINAN, D. S.; LANKFORD, J. E.; FLAMME, G. A.; STEWART, M. et al. Auditory risk estimates for youth target shooting. Int. J. Audiol. v. 53, n. 2 sup 1, p. s16-25. 2014. https://doi.org/10.3109/14992027.2013.865845

MOREIRA, M. A instrução e execução de tiro: modelos de formação, trabalho de investigação aplicada. [dissertação]. Lisboa: Academia Militar; 2009. Disponível em:

$<$ https://comum.rcaap.pt/bitstream/10400.26/8092/1/Asp\%20Manuel\%20Moreira.pdf>.

NASCIMENTO NETO, L. I.; MACHADO, D. G. S.; AGRÍCOLA, P. M. D.; FARIAS JUNIOR, L. F.; FONTELES, A. I.; SILVA, S. K. A.; et al. Efeito do esforço físico no desempenho de tiro de policiais militares do batalhão de choque. Rev. Bras. Med. Esporte. v. 23, n. 2, p. 109-113. 2017. https://doi.org/10.1590/1517869220172302159086

NEVES, E. B. Gerenciamento do risco ocupacional no Exército Brasileiro: aspectos normativos e práticos. Cad. Saúde Pública. v. 23, n. 9, p. 2127-2133. 2007. https://doi.org/10.1590/S0102-311X2007000900020

NEVES, E. B.; MELLO, M. G. S. O uso de dispositivos de proteção auditiva nos tiros de fuzil e de artilharia. Cad. Saúde Coletiva., v. 15, n. 1. p. 97-116. 2007

NEVES, E. B.; MELLO, M. G. S. O risco da profissão militar na cidade do Rio de Janeiro em "tempo de paz": a percepção da tropa. Ciênc. Saúde Colet. v.14, n. 5. p. 1699-1707. 2009. https://doi.org/10.1590/S141381232009000500011

NR-15. Norma Regulamentadora - NR-15. Ministério do Trabalho e Emprego. Portaria 3.214, de julho de 1978. Normas Regulamentadoras de segurança e saúde no trabalho (NR-15): atividades e operações insalubres. Brasília: Editora do Ministério do Trabalho e Emprego; 1978.

PACHECO, F. C. Sistemas de prevenção ao fratricídio aplicáveis à FT subunidade blindada. Liderança Militar. v. 1, n. 1, p. 69-85. 2004.

PARK, S. H.; LEE, K.; LOCKHART, T.; KIM, S. Effects of sound on postural stability during quiet standing. J. Neuroeng. Rehabil.v. 8, p. 67. 2011. https://doi.org/10.1186/1743-0003-8-67

PATTI, A.; BIANCO, A.; SAHIN, N.; SEKULIC, D.; PAOLI, A.; IOVANE, A, et al. Postural control and balance in a cohort of healthy people living in Europe: An observational study. Medicine (Baltimore)., v. 52, n. 97, p. e13835. 2018. https://doi.org/10.1097/MD.0000000000013835

PIMENTEL, B. N.; FEDOSSE, E.; RODRIGUES, N. G. S.; CRUZ, K. S.; FILHA, V. A. V. S. Percepção do ruído, saúde auditiva e qualidade de vida de professores de escolas públicas. Audiol. Commun. Res. v. 21, n. e1740, p. 1-7. 2016. https://doi.org/10.1590/2317-6431-2016-1740

PINHO, B. D. V. N. D. Influência do equilíbrio na prova de tiro, na modalidade de pentatlo moderno: estudo efectuado a atletas com experiência na modalidade. [dissertação]. Vila Real: Universidade de Trás-os-Montes e Alto Douro; 2011. Disponível em: < https://repositorio.utad.pt/handle/10348/6545>.

SIEDLECKA, B.; SOBERA, M.; SIKORA, A.; DRZEWOWSKA, I. The influence of sounds on posture control. Acta. Bioeng. Biomech., v. 17, n. 3, p. 95-102. 2015.

STEWART, C.; YU, Y.; HUANG, J.; MAKLAD, A.; TANG, X.; ALLISON, J., et al. Effects of high intensity noise on the vestibular system in rats. Hear. Res., v. 335, n. 1. p. 118-127. 2016.

https://doi.org/10.1016/j.heares.2016.03.002 
Stabilometric changes due...

BERNARDO, L. D. et al.

TALCOTT, K. A.; CASALI, J. G.; KEADY, J. P.; KILLION, M. C. Azimuthal auditory localization of gunshots in a realistic field environment: effects of open-ear versus hearing protection-enhancement devices (HPEDs), military vehicle noise, and hearing impairment. Int. J. Audiol.; v. 51, n. 1 sup 1, p. s20-30. 2012. https://doi.org/10.3109/14992027.2011.631591

TAVERNIERS, J.; DE BOECK, P. Force-on-force handgun practice: an intra-individual exploration of stress effects, biomarker regulation, and behavioral changes. Hum. Factors. v. 56, n. 2, p. 403-413. 2014. https://doi.org/10.1177/0018720813489148

XU, H.; OHGAMI, N.; HE, T.; HASHIMOTO, K.; TAZAKI, A.; OHGAMI, K, et al. Improvement of balance in young adults by a sound component at $100 \mathrm{~Hz}$ in music. Sci. Rep. v. 8, n. 16894, p. 1-8. 2018.

https://doi.org/10.1038/s41598-018-35244-3

YOON, J. J.; YOON, T. S.; SHIN, B. M.; NA, E. H. Factors affecting test results and standardized method in quiet standing balance evaluation. Ann. Rehabil. Med. v. 36, n. 1, p. 112-118. 2012.

https://doi.org/10.5535/arm.2012.36.1.112 